\title{
A Associação Brasileira de Enfermagem
}

"70 anos"

Ao falar da ABEn e seus 70 anos, alguns aspectos são pontuados objetivando, com simplicidade, a compreensão de sua história.

Em 1926, um grupo de enfermeiras, ex-alunas da Escola de Enfermagem Anna Nery, do Estado do Rio de Janeiro, entre elas: Maria Francisca de Almeida Reis, Rimidia Bandeira de Souza Gayoso, Judith Arêas, Isolina Saldanha de Lossio, Izaura Barbosa Lima, Odete Seabra, Cecy Clausen e Heloísa Maria Carvalho Veloso, concretizou uma idéia em prol do crescimento da enfermagem: criação da "ASSOCIAÇÃO NACIONAL DE ENFERMEIRAS DIPLOMADAS (ANED), em 12 de agosto.

Os designativos foram sendo alterados e, em 1953, passou a ser chamada de Associação Brasileira de Enfermagem (ABEn).

Os objetivos que nortearam os trabalhos da Associação foram: luta pelo desenvolvimento da enfermagem no Brasil, apropriar todo o campo de conhecimento da enfermagem pelo enfermeiro e fortalecer o espírito corporativo, privilegiando o status social e cultural, período em que a enfermagem profissional se instalava no país, seguindo o modelo "nightingaleano". Porém, com a consolidação e a expansão da profissão, estes objetivos se globarizaram, atendendo às necessidades e perspectivas da enfermagem.

A ABEn é uma sociedade civil, com personalidade jurídica, que congrega enfermeiros, técnicos de enfermagem e estudantes de 
graduação que a ela se associam individual e livremente. Tem número ilimitado de sócios e se organiza nacionalmente através de seções estaduais e regionais, sob a direção de uma diretoria nacional.

Sua estrutura e finalidade the confere caráter cultural, científico e político. Assume compromissos com a defesa, desenvolvimento e consolidação da enfermagem, como prática social, essencial na assistência e organização dos serviços de saúde.

A ABEn assessorou na criação das Escolas de Enfermagem, na formação do currículo mínimo para os cursos dos profissionais de enfermagem, estruturação e regulamentação da enfermagem como profissão no Brasil. Também elaborou e acompanhou o anteprojeto que se transformou na Lei $n^{0} 2.604 / 55$, que regulamentou o exercício da profissão de enfermagem; e lutou pela lei $n^{\circ} 5.905 / 73$ que dispõe sobre a criação dos Conselhos Federal e Regionais de Enfermagem.

De 1926 a 1976, a ABEn foi a única entidade de enfermagem a lutar pela categoria. A história da ABEn é a história da enfermagem brasileira. 